\title{
Contents, Vol. 192, 1986
}

No. 1 Original Paper - Travaux originaux Originalarbeiten

Silicone Oil Particles Trapped in the Subretinal Space: Complications after Substitution of the Vitreous

Honda, Y.; Ueno, S.; Miura, M.; Yamaguchi, H 1

Interferon- $\beta$ Treatment of Herpes Simplex Keratitis

Vannini, A.; Cembrano, S.; Assetto, V.; Giannitelli, A 6

Immediatwirkung topischer B-Blocker auf die «Breakup time»

Strempel, $1 \quad 11$

Two Japanese Cases of Battered Child Syndrome with Retinal Hemorrhage

Hosokawa, T.; Hayasaka, S.; Yabata, K.; Tateda, H 17

Optic Neuropathy of Graves' Disease. A Report of a Perimetric Follow-Up

Gasser, P.; Flammer, J 22

Familial Optic Atrophy with Sex-Influenced Severity. A New Variety of Autosomal-Dominant Optic Atrophy?

Gorgone, G.; Li Volti, S.; Cavallaro, N.; Conti, L.; Profeta, G.M.; Mollica, F 28

Steroids and Neuroendocrine Hormones Detected by the Immunoperoxidase Technique from Malignant Melanomas and Nevi of the Choroid and Conjunctiva (With 1 color plate)

Di Tondo, U.; Balestrazzi, E.; Santeusanio, G.; Pintucci, S.; Spadea, L 34

Small Choroidal Melanoma with Diffuse Orbital Involvement Detected and Differentiated with Standardized Echography - with Special Reference to the Reliability of Sonography in Predicting Scleral Tumoral Infiltration

Rochels, R.; Nover, A 39

Penetration of 14C-Methisoprinol into Rabbit Eyes with Experimentally Induced Herpetic

Keratitis

Alberghina, M.; Tognon, M.; Cassai, E.; Gorgone, G.; Cavallaro, N.; Filippello, M.;

Scaletta, $\mathrm{S} \quad 46$

NMR-Tomographie des menschlichen Auges (NMR Tomography of the Human Eye)

Seiler, T.; Wollensak, J.; Miszalok, V

Clinicopathologic Case Report Description clínico-pathologique de cas · Klinisch-pathologische

Fallbeschreibung

Paranasal Sinus Adenocarcinoma Causing Proptosis

Burns, H.; Mullaney, J

57

Book Reviews $\cdot$ Livres nouveaux $\cdot$ Buchbesprechungen

No. 2 Original Paper Travaux originaux Originalarbeiten

In vivo Experiments with the Excimer Laser - Technical Parameters and Healing Processes

Seiler, T.; Wollensak, J 65

Der Einfluss von UV-Bestrahlung auf Trevirafàden

Kothe, H.-W.; Wagner, H.; Haustein, L.; Hauffe, W 71

Intraocular and Extraocular Colobomatous Cysts in Adults 


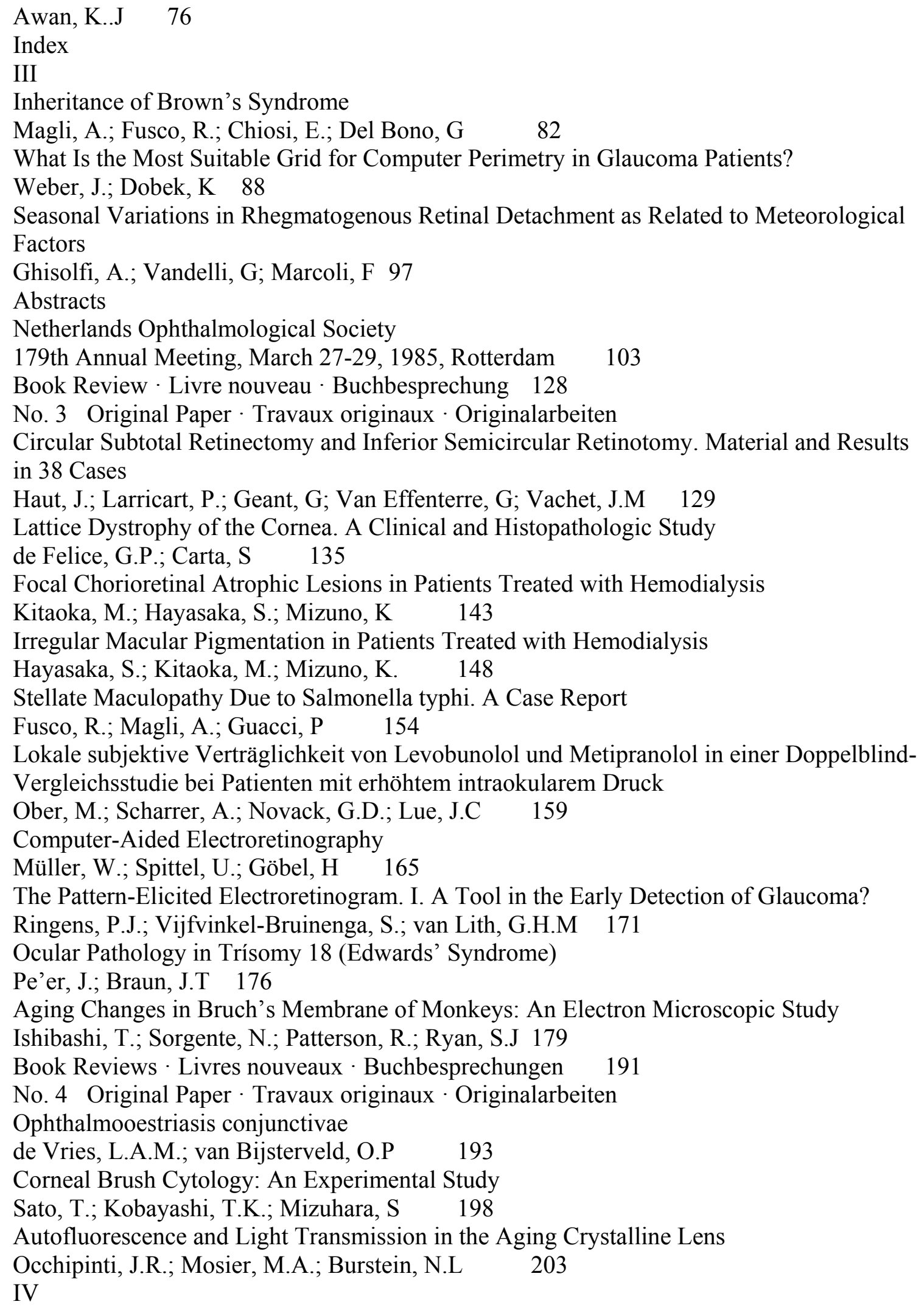


Index

Modification by Fluoangiography of Color Vision in Diabetic Patients

Fontana, M.; Verriest, G 210

The Pattern-Elicited Electroretinogram. II. Retinal Responses in Retrobulbar Neuritis

Ringens, P.J.; van Lith, G.H.M.; v.d. Poel, H217

The 'Flicker Test' According to Aulhorn in the Diagnosis of Acute Optic Neuritis

Christ, Th.; Pillunat, L.E.; Stodtmeister, R 220

First Results of the Computer-Aided Classification of Electroretinograms

Müller, W.; Spittel, U.; Göbel, H 228

Myasthenia gravis and Recurrent Retrobulbar Optic Neuritis: An Unusual Combination of

Diseases

Mapelli, G.; De Palma, P.; Franco, F.; Fini, M

Localized Conjunctival Amyloidosis: Case Reports and Review of Literature

Rosenblatt, M.; Spitz, G.F.; Friedman, A.H.; Kazam, E.S 238

Book Reviews — Livres nouveaux — Buchbesprechungen 246

Author Index 249

Subject Index 251

S. Karger - Medical and Scientific Publishers

Basel · München · Paris · London · New York · New Delhi · Singapore · Tokyo a Sydney

Drug Dosage

The authors and the publisher have exerted every effort to ensure that drug selection and dosage set forth in this text are in accord with current recommendations and practice at the time of publication. However, in view of ongoing research, changes in government regulations, and the constant flow of information relating to drug therapy and drug reactions, the reader is urged to check the package insert for each drug for any change in indications and dosage and for added warnings and precautions. This is particularly important when the recommended agent is a new and/or infrequently employed drug.

All rights reserved.

No part of this publication may be translated into other languages, reproduced or utilized in any form or by any means, electronic or mechanical, including photocopying, recording, microcopying, or by any information storage and retrieval system, without permission in writing from the publisher or, in the case of photocopying, direct payment of a specified fee to the Copyright Clearance Center (see 'Information for Readers and Subscribers').

(C) Copyright 1986 by

S. Karger AG, P.O. Box, CH-4009 Basel (Switzerland)

Printed in Switzerland by

Buchdruckerei Friedrich Reinhardt AG, Basel 